\section{IRRIGATION THROUGH THE AGES}

$\mathrm{O}^{\mathrm{N}}$ February 16, Mr. E. Bruce Ball, president of the Institution of Mechanical Engineers, delivered an address in the course of which he surveyed "The Influence of the Mechanical Mind on the Development of Irrigation through the Ages".

From the dawn of civilization there is evidence of the activity of the mechanical mind in devising means of watering those tracts of land which could in this way be made highly fertile. Something here might have been said of the skill with which these unlettered people constructed the small channels by which the water was distributed to the fields.

The mechanical devices were introduced at the points at which the water was raised from some stream or well into the basins which supplied the system of channels. The earliest of those was probably what is known as the 'basket scoop', a hemispherical vessel operated by two men by means of two ropes each so that it could be swung up with its load of water and tilted to discharge it. The method is still in use in India and China and gives a lift of about 3 feet. The need for higher lifts and for making better use of available labour led to developments showing great ingenuity in the application of the only available material, timber. The hollowed tree trunk nicely balanced so as to enable one man to operate it, and the moving counterpoise on a balanced beam showed a keen appreciation of mechanical principles. Further improvements on these designs gave increased lift, or effected a saving of energy-no doubt that of the user himself-or again added a simple automatic device to discharge the water when it had reached its full lift or, as in another case, made use of gravity by means of a sloping path to assist tractive effort.

All these methods gave intermittent deliveries-- a bucketful at a time-and we then see an important development in the production of a crude wheel carrying a number of buckets and giving an almost continuous delivery. Operated by an ox or a camel through a rough and ready form of gearing, this shows the conception of the machine being evolved. Several illustrations of different pumping or water lifting machines were shown, including one of the gigantic wheel on the Yellow River, and portable link chain pumps. While these and even the most primitive methods of irrigation can still be seen in use in many parts of Asia, and appear but puny efforts as compared with the great engineering works of to-day, it must be borne in mind that the latter have only been made possible by the new materials of construction now available and the machines and power units at the disposal of the great constructors of recent times.

Examples of the great barrages were referred to and illustrations of them and of the machinery essential to their operation shown. The different types of sluice gates and shutters and the system by which the waters are controlled were explained, thus showing how the mechanical mind has harnessed the waters to the purpose of assisting Nature to maintain the population of the world; and although much has been done there are vast resources still awaiting development. Mr. Bruce Ball claims this as but a single illustration of the dependence of human life on the creative work of the mechanical engineer.

\section{SEVENTY YEARS AGO}

\author{
NATURE, vol. 2, May 5, I870
}

First Number of the Second Volume of NATURE

Sir Norman Lockyer, founder and editor, opens No. 27 of this journal with a short article referring to the achievements of the past six months. He remarks on the encouragement, and criticism, which he has received. "It has been our endeavour to carry out our programme by making the journal useful to workers in science; worthy therefore of their perusal, and therefore, again, worthy of their contributions: and by thus extending our appeal beyond the limits of the scientific world on the one hand, and endeavouring to keep up the dignity of science herself on the other, we have already met with an encouraging response. Our subscribers now number nearly five thousand ; that is, we have, on a moderate estimate, fifteen thousand readers. . . .

"We state this, not only because the statement is almost due to our contributors as a justification of our demands on their time, but because it indicates the work-we almost said the noble work-which lies before them. Surely at a time when England would gain so much by the scientific education, not only of her Workmen but of her Ministers, an attempt to place Science before the Public, week by week, as Politics, Art, Music, and a hundred other things are placed before them, must not be suffered to flag; when the number of science-teachers and sciencestudents is daily increasing, and the necessity for combined action and representation among scientific men themselves is being more and more felt, the popularization of science becomes more important than ever."

\section{Why is the Sky Blue?}

"H. A. N." has a letter under this title. He remarks: "Is it that the predominant colour of sunlight being orange, the regions devoid of sunlight appear of the complementary colour ? . . . Or, again, is the blueness merely the colour of our atmosphere, as Prof. Tyndall's experiments have led some to believe? In favour of the former explanation, is the fact that the maximum intensity of the light of the solar spectrum is in the orange, and indeed that the sun looks orange, and if we close our eyes after gazing a moment at him when high up in the sky, we see a blue image. When the sun is low, his colour changes from orange to red, and this would explain the green tints so often seen in the cloudless parts of the sky at sunset."

Aт a meeting of the German Chemical Society on March 28, Prof. Rammelsberg read a paper on the phosphates of thallium, in which he stated that isomorphism exists between certain hydrogen thallium and hydrogen ammonium phosphates. $\mathrm{He}$ claims this is the first proof of the isomorphism of hydrogen with monatomic metals.

Mr. (afterwards Sir) F. B. TyLor read a paper "On the Philosophy of Religion among the Lower Races of Mankind" before the Ethnological Society on April 26. He said that the conception of the soul as recognized by the lower races is the starting point of their religious philosophy, which he described as 'animism'.

A Naturad History Society has been established at Winchester College. 